\title{
Wpływ przepisów wymuszających swoje zastosowanie na rozstrzyganie spraw spadkowych pod rządami rozporządzenia Parlamentu Furopejskiego i Rady (UE) Nr 650/2012*
}

\begin{abstract}
Since August 17, 2015 the courts of the Member States of the European Union apply the conflict-of-laws rules adopted in the EU Succession Regulation (EU) in succession matters. From the Polish point of view, this constitutes not only the change of the rules applied for the purposes of determining jurisdiction and the applicable law, but also a new approach to the overriding mandatory provisions.

Contrary to other European instruments of private international law, the Succession Regulation neither uses the term "overriding mandatory provisions", nor defines its meaning. Nevertheless, in Article 30 the Regulation provides for application - irrespective of the law applicable to the succession under its conflict rules - of the special rules of the State, where certain immovable property, enterprises or other special categories of assets are located, and which — for economic, family or social considerations - impose restrictions concerning or affecting the succession in respect of those assets, in so far as, under the law of that State, they are applicable irrespective of the law applicable to the succession.
\end{abstract}

The interpretation of this provision cause difficulties. It is not clear whether the concept of the special provisions embodied in Article 30 refers to the concept of overriding mandatory rules, well known in the European private international law, or whether

a) Dr hab., Uniwersytet Kardynała Stefana Wyszyńskiego w Warszawie.

* Rozporządzenie Parlamentu Europejskiego i Rady (UE) Nr 650/2012 z 4.07.2012 r. w sprawie jurysdykcji, prawa właściwego, uznawania i wykonywania orzeczeń, przyjmowania i wykonywania dokumentów urzędowych dotyczących dziedziczenia oraz w sprawie ustanowienia europejskiego poświadczenia spadkowego. Dz.Urz. UE L 2012.201.107. 
it constitutes an original solution. Another controversial issue discussed in the paper is the relevance of the mandatory rules of the forum or the third State other than those mentioned in Article 30.

Keywords: Succession Regulation, succession matters, choice of law, connecting factor, applicable law, overriding mandatory provisions, special rules

\section{Uwagi wprowadzające}

Nauce prawa prywatnego międzynarodowego znana jest od dawna koncepcja przepisów wymuszających swoje zastosowanie. Pojęcia tego używa się na oznaczenie norm imperatywnych w znaczeniu kolizyjnoprawnym, a więc regulacji, będących wyrazem idei ochrony szczególnie ważnych interesów publicznych państwa ich pochodzenia, które zgodnie z wolą danego prawodawcy powinny znaleźć zastosowanie do wszystkich stanów faktycznych mieszczących się w zakresie ich hipotezy, bez względu na prawo właściwe do oceny danego stosunku w normalnym toku rze$\mathrm{czy}^{1}$.

Obszarem stosunków cywilnoprawnych, w którym tradycyjnie można dostrzec ich oddziaływanie, sa sprawy spadkowe. W prawie krajowym wielu państw występuja regulacje merytorycznoprawne stworzone, by wywierać wpływ na dziedziczenie majątku po zmarłym, niezależnie od postanowień statutu spadkowego. Nie tworza one jednolitej grupy. Mogą odnosić się zarówno do wybranych kategorii składników majątku, jak i funkcjonowania niektórych instytucji bądź osób zaufania publicznego, a także strzec swobody dokonywania rozrządzeń spadkowych czy zabezpieczać interesy członków najbliższej rodziny zmarłego. Specyficzną grupę stanowią wśród nich przepisy, które w oderwaniu od postanowień statutu spadkowego, wprowadzają szczególne reguły w odniesieniu do dziedziczenia wybranych składników spadku (nieruchomości bądź ich wybranych typów, gospodarstw rolnych, przedsiębiorstw, dóbr rodowych, lenn czy mieszkań rodzinnych), położonych na obszarze państwa ich pochodzenia. Mogą one sprowadzać się np. do zakazu rozdrabniania mas majątkowych, wymogu posiadania przez spadkobierców szczególnych kwalifikacji osobistych czy wręcz polegać na poddaniu danej ka-

${ }^{1} \mathrm{Na}$ temat samego pojęcia oraz cech przepisów wymuszających swoje zastosowanie w literaturze polskiej por. zwłaszcza monografie: B. Fuchs: Statut kontraktowy a przepisy wymuszajace swoje zastosowanie. Katowice 2003 oraz M. Mataczyński: Przepisy wymuszajace swoje zastosowanie w prawie prywatnym międzynarodowym. Kraków 2005. 
tegorii składników majątku odrębnemu porządkowi dziedziczenia ${ }^{2}$. Odrębne miejsce zajmuja natomiast przepisy wprowadzajace ograniczenia w dokonywaniu rozrządzeń spadkowych na rzecz niektórych kategorii osób wykonujących zawody bądź pełniących funkcje zaufania publicznego: notariuszy, lekarzy, spowiedników czy personelu placówek opiekunczych $^{3}$.

Znaczenie tego rodzaju norm obowiazujacych w państwie forum i odnoszacych się do położonych tam składników spadku nigdy nie budziło wątpliwości nawet $\mathrm{w}$ braku $\mathrm{w}$ danym systemie prawnym odrębnej, pisanej normy kolizyjnej. Potwierdza to także praktyka orzecznicza polskich sąów pod rządami przepisów szczególnych o dziedziczeniu gospodarstw rolnych ${ }^{4}$. Różnie tłumaczono natomiast podstawy ich zastosowania ${ }^{5}$. Stopniowo dostrzeżono także znaczenie tego rodzaju unormowań państwa trzeciego. W braku wyraźnej regulacji prawnej podstaw ich ewentualnego dopuszczenia do głosu upatrywano w ogólnych zasadach prawa prywatnego międzynarodowego legis fori ${ }^{6}$.

W polskim krajowym prawie prywatnym międzynarodowym koncepcja przepisów wymuszających swoje zastosowanie ostatecznie znalazła swój wyraz w ogólnej normie z art. 8 PrPrywM z 2011 r., która nadal zachowuje swoje znaczenie $\mathrm{w}$ odniesieniu do spadków otwartych przed 17.08.2015 r.

Nowa jakość w powyższej materii przyniosło jednak wejście w życie przepisów rozporządzenia Parlamentu Europejskiego i Rady (UE) $\mathrm{Nr}$ 650/2012 z 4.7.2012 r. w sprawie jurysdykcji, prawa właściwego, uznawania $i$ wykonywania orzeczen, przyjmowania $i$ wykonywania dokumentów urzędowych dotyczacych dziedziczenia oraz $w$ sprawie ustanowienia eu-

${ }^{2}$ Co do przykładów takich rozwiązań por. Ł. Żarnowiec: Wptyw statutu rzeczowego na rozstrzyganie spraw spadkowych - na styku statutów. Warszawa 2018, s. 290295 oraz cytowana tam literaturę i orzecznictwo.

${ }^{3}$ Ibidem, s. $295-298$.

${ }^{4}$ Sąd Najwyższy, uchwała z dnia 28.05.1969 r., III CZP 23/69. „Orzecznictwo Sądu Najwyższego Izba Cywilna” 1970, nr 1, poz. 3; Sąd Najwyższy postanowienie z dnia 6.03.1970 r., I CR 3/70. „Państwo i Prawo” [dalej: PiP] 1971, z. 12, s. 1087 i nast.

${ }^{5}$ H. Trammer: Sprawy czysto majatkowe $w$ polskim prawie prywatnym międzynarodowym. „Prawo w Handlu Zagranicznym” 1968, nr 19-20, s. 16-17; M. Pazdan: Glosa do uchwaty Sadu Najwyższego z 28 V 1969 r., III CZP 26/69. „Orzecznictwo Sądów Polskich” 1970, nr 10, s. 123 i nast.; Idem: Dziedziczenie ustawowe w prawie prywatnym międzynarodowym. Metody regulacji właściwości prawa. Katowice 1973, s. 137-149; M. Tomaszewski: Przepisy szczególne o dziedziczeniu gospodarstw rolnych a prawo prywatne międzynarodowe. PiP 1970, z. 12, s. 917 i nast.; W. Ludwiczak: Międzynarodowe prawo prywatne. Warszawa 1971, s. 216; J.S. Piątow ski: Z zagadnień dziedziczenia gospodarstwa rolnego po cudzoziemcu. PiP 1971, z. 12, s. 995 i nast.

${ }^{6}$ M. Pazdan: Prawo prywatne międzynarodowe. Warszawa 2008, s. 80. 
ropejskiego poświadczenia spadkowego ${ }^{7}$. Jego art. 30 przewiduje wprost zastosowanie - niezależnie od postanowień statutu spadkowego wskazanego za pośrednictwem norm kolizyjnych zawartych w rozporządzeniu - takich przepisów państwa położenia niektórych nieruchomości, niektórych przedsiębiorstw lub innych szczególnych kategorii składników majątku, które w odniesieniu do nich, nakładaja z przyczyn ekonomicznych, rodzinnych lub społecznych ograniczenia dotyczące dziedziczenia lub wpływajace na dziedziczenie, w takim zakresie, w jakim na mocy prawa tego państwa mają one zastosowanie bez względu na prawo właściwe dla dziedziczenia. Wyjaśnieniu znaczenia zawartej tam normy poświęcono motyw 54 preambuły do rozporządzenia. Z jednej strony wskazuje się tam, że ze względów ekonomicznych, rodzinnych lub społecznych niektóre nieruchomości, przedsiębiorstwa i inne szczególne kategorie składników majątku podlegają szczególnym uregulowaniom w państwie członkowskim ich położenia, nakładającym ograniczenia dotyczące dziedziczenia tych składników majątku lub wpływające na ich dziedziczenie, których stosowanie należy zapewnić w rozporządzeniu. Z drugiej natomiast podkreśla się, że ze względu na konieczność zachowania zgodności z ogólnym celem rozporządzenia ten wyjattek od stosowania prawa właściwego dla dziedziczenia należy interpretować ściśle, przy czym ani normy kolizyjne poddające dziedziczenie nieruchomości przepisom prawa innego niż prawo właściwe dla majątku ruchomego, ani przepisy przewidujace udział obowiązkowy większy niż przewidziany prawem właściwym dla dziedziczenia na mocy rozporządzenia nie moga być uważane za szczególne uregulowania, nakładające ograniczenia dotyczące dziedziczenia niektórych składników majątku lub wpływające na ich dziedziczenie.

Brzmienie tego przepisu nasuwa jednak szereg watpliwości.

Otóż jego tytuł i treść nie określają wprost charakteru i znaczenia przepisów, do których odnosi się wyrażona tam norma prawna. Rozporządzenie nie kwalifikuje ich w sposób wyraźny jako przepisów wymuszających swoje zastosowanie ani — w odróżnieniu od art. 9 rozporządzenia Rzym I ${ }^{8}$ - nie zawiera ich definicji legalnej.

${ }^{7}$ Ilekroć w niniejszym artykule pojawi się określenie „rozporządzenie” bez bliższego doprecyzowania, oznacza ono rozporządzenie Parlamentu Europejskiego i Rady(UE) Nr 650/2012 z dnia 4.07.2012 r. w sprawie jurysdykcji, prawa właściwego, uznawania i wykonywania orzeczeń, przyjmowania i wykonywania dokumentów urzędowych dotyczących dziedziczenia oraz w sprawie ustanowienia europejskiego poświadczenia spadkowego.

${ }^{8}$ Rozporządzenie Parlamentu Europejskiego i Rady (WE) $\mathrm{Nr} 593 / 2008$ z dnia 17.06.2008 r. w sprawie prawa właściwego dla zobowiązań umownych (Rzym I). Dz.Urz. UE L 2008.177.6 ze zm. 
Nie wypowiada się również jednoznacznie co do znaczenia wskazanej kategorii przepisów przy ocenie sprawy spadkowej. Nasuwa się wobec tego pytanie, czy sądowi orzekającemu przysługuje swoboda decyzji co do zastosowania bądź pominięcia nienależących do statutu spadkowego norm prawnych legis sitae o wskazanych tam cechach (o ile oczywiście one same „chca” znaleźć w danym wypadku zastosowanie), czy też (w granicach zgodności z porządkiem publicznym forum) ma on obowiązek ich zastosowania niezależnie od postanowień legis successionis.

Przepis art. 30 nie wypowiada się wreszcie wprost co do znaczenia pod rządami rozporządzenia innych niż tam wyraźnie wskazane przepisów, z których treści, funkcji czy celów wynika wola zastosowania niezależnie od prawa w normalnym toku rzeczy właściwego.

Celem niniejszego artykułu jest analiza wpływu przepisów wymuszajacych swoje zastosowanie na rozstrzyganie spraw spadkowych pod rządami rozporządzenia oraz próba oceny przyjętego w nim rozwiązania pod kątem ewentualnych zmian.

\section{Przepisy szczególne objęte zakresem zastosowania normy z art. 30}

\subsection{Kryteria wyróżnienia przepisów, o których mowa w art. 30}

Artykuł 30 rozporządzenia, w znacznie węższym zakresie od odpowiednich uregulowań znanych z art. 9 rozporządzenia Rzym I (w odniesieniu do zobowiązań umownych) oraz art. 16 rozporządzenia Rzym $\mathrm{II}^{9}$ (dla zobowiązań pozaumownych), reguluje podstawę dopuszczenia do głosu przy rozstrzyganiu spraw spadkowych przepisów szczególnych pochodzacych spoza legis causae ${ }^{10}$. Mowa jest w nim jedynie o normach szczególnych, należących do państwa położenia składników spadku, które w odniesieniu do niektórych nieruchomości, niektórych przedsiębiorstw lub innych szczególnych kategorii składników majątku, nakładaja z przyczyn ekonomicznych, rodzinnych lub społecznych ograniczenia dotyczące dziedziczenia lub wpływające na dziedziczenie. Pod tym wzglę-

${ }^{9}$ Rozporządzenie Parlamentu Europejskiego i Rady (WE) $\mathrm{Nr}$ 864/2007 z dnia 11.07.2007 r. dotyczące prawa właściwego dla zobowiązań pozaumownych (Rzym II). Dz.Urz. UE L 2007.199.40.

${ }^{10}$ A. Köhler, in: Internationales Erbrecht. EuErbVO, IntErbRVG. Hrsg. A. Köhler, W. Gierl, L. KroiB, H. Wilsch. Baden-Baden 2015, s. 131. 
dem rozporządzenie spadkowe wyraźnie nawiąuje do art. 15 Konwencji haskiej z 1.8.1989 r. o prawie właściwym dla dziedziczenia ${ }^{11}$, zarazem odchodząc od rozwiązań przyjętych we wcześniejszych unijnych instrumentach jednolitego prawa kolizyjnego ${ }^{12}$.

Przepisy szczególne, o których mowa, są wyznaczane tutaj z wykorzystaniem kryterium przedmiotu regulacji, celu, szczególnego charakteru prawnego oraz miejsca ich pochodzenia.

\subsection{Kryterium przedmiotu regulacji}

Gdy chodzi o pierwszy z wymienionych powyżej elementów, art. 30 rozporządzenia wskazuje na szczególne przepisy, nakładające ograniczenia dotyczące dziedziczenia lub wpływające na dziedziczenie niektórych składników spadku. Oznacza to, że przedmiot regulacji przepisów, o których mowa, odnosić się ma do dziedziczenia majątku po zmarłym. Wydaje się jednak, iż pojęcie to należy rozumieć szeroko ${ }^{13}$, kierując się nie tyle definicją dziedziczenia zawartą $\mathrm{w}$ art. 3 ust. 1 lit. a rozporządzenia, ile raczej zakresem zastosowania statutu spadkowego, wyznaczonym przez normę $\mathrm{z}$ art. 23. Nic zatem nie stoi na przeszkodzie uznaniu za przepisy szczególne w rozumieniu art. 30 unormowań wprowadzających ograniczenia dochodzące do głosu dopiero na etapie wspólności majątku spadkowego, zarządu nim ${ }^{14}$ czy działu spadku.

${ }^{11}$ RCDIP 1988, n 4, s. 806-815, przekł. na j. pol. A. Juryk, A. Wysocka. „Kwartalnik Prawa Prywatnego" 2007, z. 2, s. 569-589.

12 Taki kształt przyjętej w rozporządzeniu regulacji może nasuwać wręcz wątpliwości co do tego, czy w ogóle jest ona wyrazem koncepcji przepisów wymuszajacych swoje zastosowanie, art. 30 kwestii tej bowiem wprost nie rozstrzyga - por. M.A. Zachariasiewicz: Przepisy wymuszajace swoje zastosowanie a statut spadkowy. W: Nowe europejskie prawo spadkowe. Red. M. Pazdan, J. Górecki. Warszawa 2015, s. 318; M. Pazdan: Zarzad sukcesyjny - aspekty kolizyjnoprawne. W: Prawo handlowe. Między teoria, praktyka a orzecznictwem. Księga Jubileuszowa dedykowana Profesorowi Januszowi A. Strzępee. Red. E. Zielińska, P. Pinior, P. Relidzyński, W. Wyrzykowski, M. Żaba. Warszawa 2019, s. 73. Kwalifikację taka jednakże bez zastrzeżeń - moim zdaniem trafnie - przyjmuja: F.M. Wilke: Das internationale Erbrecht nach der neuen EU-Erbrechtsverordnung. „Recht der Internationalen Wirtschaft” [dalej: RIW] 2012, H. 9, s. 607; P. Lagarde, in: EU Regulation on Succession and Wills. Commentary. Eds. U. Bergquist, D. Damascelii, R. Frimston, P. Lagarde, F. Odersky, B. Reinhartz. Köln 2015, s. 166 czy N. Davrados, in: EU Succession Regulation No 650/2012. A Commentary. Eds. H.P. Pamboukis. C.H. Beck, Hart, Nomos 2017, s. 370 , przyp. 53.

${ }^{13}$ M. Pazdan: Zarzqd sukcesyjny..., s. 73.

${ }^{14}$ Ibidem. 
Do uznania, że mamy do czynienia z przepisem, o którym mowa w art. 30, nie jest również konieczne, by przedmiotem swej regulacji obejmował on wyłącznie materię prawa spadkowego. Należy brać zatem pod uwagę także i takie przepisy, które wprowadzaja szczególne uwarunkowania w odniesieniu do nabycia wybranych składników majątku bez względu na jego tytuł, o ile zakresem swym obejmują również dziedziczenie.

Norma z art. 30 rozporządzenia, nie odnosi się natomiast do ewentualnych przepisów państwa położenia poszczególnych składników majątku spadkodawcy, regulujących nabycie bądź przenoszenie wybranych kategorii praw majątkowych $\mathrm{w}$ związku ze śmiercią danej osoby w trybie innym niż dziedziczenie. Znajduja one zastosowanie do oceny takiego nabycia w ramach właściwości legis causae, tj. prawa, któremu dany składnik majątku podlega ze względu na swoja naturę a skutkiem ich zastosowania może być po prostu wyłączenie takiego dobra ze spadku ${ }^{15}$.

\subsection{Szczególny charakter regulacji}

Drugą cechą decydująca o możliwości zakwalifikowania danego przepisu do zakresu normy z art. 30 rozporządzenia jest jego szczególny charakter. Chodzi tutaj wyłącznie o regulacje, które w odniesieniu do dziedziczenia niektórych składników majątku wprowadzają reguły odmienne od obowiąujących dla spadku jako całości w państwie jego położenia ${ }^{16}$. Artykuł 30 rozporządzenia nie obejmuje zatem ewentualnych przepisów kreujących szczególny reżim dziedziczenia całego spadku np. z przyczyn natury podmiotowej ${ }^{17}$.

Rozporządzenie, nawiązując w art. 30 do przepisów legis sitae wprowadzających szczególne uwarunkowania związane z dziedziczeniem wybranych składników spadku, zawiera jedynie przykładowe wyliczenie tego rodzaju dóbr. Na jego podstawie zastosowanie znaleźć mogą również regulacje odnoszace się do innych składników spadku ${ }^{18}$ czy nawet całych mas majątkowych jak np. gospodarstwa rolne ${ }^{19}$. Nie ma przy tym znaczenia, jak w realiach konkretnego przypadku przedstawia się ich stosunek

${ }^{15}$ Ł. Żarnowiec: Wptyw statutu rzeczowego..., s. 314.

${ }^{16}$ A. Dutta, in: Münchener Kommentar zum Bürgerlichen Gesetzbuch. T. 10. Hrsg. J. v. Hein. München 2015, s. 1570.

${ }^{17}$ M.A. Zachariasiewicz: Przepisy wymuszajace..., s. 331.

${ }^{18}$ M. Mataczyński: Przepisy ograniczajace dziedziczenie na tle art. 30 rozporzadzenia spadkowego. W: Nowe europejskie prawo spadkowe. Red. M. Pazdan, J. Górecki. Warszawa 2015, s. 292.

${ }^{19}$ M.A. Zachariasiewicz: Przepisy wymuszajace..., s. 333. 
ilościowy czy wartościowy do pozostałych składników masy spadkowej po danym spadkodawcy.

\subsection{Wartości realizowane przez przepisy dochodzące do głosu za pośrednictwem art. 30 rozporządzenia}

Kolejnym kryterium, do którego odwołuje się norma z art. 30 rozporządzenia, są określone wartości, stojące za wprowadzeniem przez państwo położenia danego dobra szczególnych przepisów, ograniczających bądź wpływających na jego dziedziczenie. Prawodawca unijny wskazuje tutaj na przyczyny ekonomiczne, rodzinne lub społeczne. Nie zostały one jednak w żaden sposób doprecyzowane ani nawet uzupełnione poprzez odwołanie się do jakiegokolwiek kryterium wartościującego. Takie podejście wyraźnie odbiega od rozwiązania znanego z art. 9 ust. 1 rozporządzenia Rzym I ${ }^{20}$, a w praktyce może utrudniać odróżnienie przepisów, o których mowa, od zwykłych norm bezwzględnie wiążących państwa położenia danego składnika spadku. Ryzyko to jest w tym wypadku o tyle realne, że naturalna niejako cechą wszystkich przepisów prawa spadkowego jest ich ukierunkowanie na realizację wartości rodzinnych, ekonomicznych oraz społecznych ${ }^{21}$. Zatem odwołanie się do nich jako kryterium wyróżnienia spośród ogółu norm dotyczących dziedziczenia ich wybranej kategorii niczego nie wyjaśnia ${ }^{22}$.

Wydaje się jednak, że do zawartego w art. 30 wyliczenia, także i w tym wypadku nie należy przywiązywać nadmiernej wagi. Zależność między tkwiącym w przepisach wymuszających swoje zastosowanie pierwiastkiem kolizyjnym a realizacją szczególnie ważnych interesów publicznych państwa ich pochodzenia stanowi ich naturalną i powszechnie

${ }^{20}$ Zgodnie z jego treścią wypracowaną na podstawie wyroku ETS z dnia 23.11.1999 r. w połaczonych sprawach C-369/96 Jean-Claude Arblade and Arblade \& Fils SARL i C-376/96 Bernard Leloup, Serge Leloup and Sofrage SARL, Rec. 1999, s. I-08453: „Przepisy wymuszające swoje zastosowanie to przepisy, których przestrzeganie uważane jest przez państwo za tak istotny element ochrony jego interesów publicznych, takich jak organizacja polityczna, społeczna lub gospodarcza, że znajduja one zastosowanie do stanów faktycznych objętych ich zakresem bez względu na to, jakie prawo jest właściwe dla umowy zgodnie z [...] rozporządzeniem".

${ }^{21}$ J. Gwiazdomorski: Prawo spadkowe w zarysie. Warszawa 1985, s. 31; J.S. Piatowski: Prawo spadkowe. Zarys wykładu. Warszawa 1987, s. 16-20; R. Frank, T. Helms: Erbrecht. München 2013, s. 1-2; D. Leipold: Erbrecht. Tübingen 2014, s. $25-26$.

${ }^{22}$ A. Dutta, in: Münchener..., s. 1570; M. Mataczyński: Przepisy ograniczajace..., s. 293. 
akceptowaną cechę $e^{23}$. Zatem również w przypadku przepisów, o których mowa w art. 30, należy uznać ją za kryterium wyróżniające ${ }^{24}$. Na marginesie warto zaznaczyć, że taki punkt widzenia prezentowany jest powszechnie także na tle art. 16 rozporządzenia Rzym II, mimo że definiując tam przepisy wymuszające, zupełnie pominięto nawiązanie do stojących za nimi wartości ${ }^{25}$.

\subsection{Wola zastosowania niezależnie od postanowień prawa właściwego}

Ostatnim kryterium, do którego odwołuje się norma z art. 30 rozporządzenia, jest charakterystyczna dla wszystkich przepisów imperatywnych w znaczeniu kolizyjnym, wola zastosowania, niezależnie od postanowień prawa w normalnym toku rzeczy właściwego, w odniesieniu do sytuacji odpowiednio powiązanych z własnym obszarem prawnym w tym wypadku: do dziedziczenia wybranych składników spadku położonych na obszarze danego państwa. O tym, czy tego rodzaju sytuacja $\mathrm{w}$ konkretnym przypadku zachodzi, rozstrzygać należy jednak nie z perspektywy art. 30 rozporzadzenia, ale w drodze wnikliwej wykładni danej normy merytorycznej, konkretnie zaś z punktu widzenia interesów, których realizacji służy ${ }^{26}$. blade).

${ }^{23}$ ETS wyrok z dnia 23.11.1999 r., w połączonych sprawach C-369/96 i C-376/96 (Ar-

${ }^{24}$ M.A. Zachariasiewicz: Przepisy wymuszajace..., s. 333; A. Köhler, in: Internationales Erbrecht ..., s. 132-133; Ł. Żar nowiec: Wptyw statutu rzeczowego..., s. 318.

${ }^{25}$ R. Plender, M. Wilderspin: The European Private International Law of Obligations. London 2009, s. 744; T.K. Graziano: Das auf außervertragliche Schuldverhältnisse anzuwendende Recht nach Inkrafttreten der Rom II - Verordnung. „Rabels Zeitschrift für ausländisches und internationales Privatrecht” 2009, Nr. 73, s. 72; C. Brière: Le règlement (CE) $n^{\circ} 864 / 2007$ du 11 juillet 2007 sur la loi applicable aux obligations non contractuelles (Rome II). „Revue trimestrielle LexisNexis JurisClasseur” Janvier-Février-Mars 2008, s. 66; A. Junker: Die Rom II - Verordnung: Neues Internationales Deliktsrecht auf europäischer Grundlage. „Neue Juristische Wochenschrift” 2007, Nr. 51, s. 3680; D. Jakob, P. Picht, in: Europäisches Zivilprozess- und Kollisionsrecht EuZPR/EuIPR Kommentar. Hrsg. T. Rauscher. Műnchen 2011, s. 965-966; G. Hohloch, in: Erman. Handkommentar zum Bürgerlichen Gesetzbuch. Bd. 2. Köln 2011, s. 6795; Ł. Żarnowiec, w: „System Prawa Prywatnego”. T. 20B: Prawo prywatne międzynarodowe. Red. M. Pazdan. Warszawa 2015, s. 864.

${ }^{26}$ A. Dutta, in: Münchener..., s. 1570; A. Köhler, in: Internationales Erbrecht..., s. 133; M. Mataczyński: Przepisy ograniczajace..., s. 293-294. Jak słusznie podkreśla R. Freitag, na tle art. 9 rozporządzenia Rzym I oraz art. 16 rozporządzenia Rzym II normy te nie są klasycznymi normami kolizyjnymi, wyznaczającymi prawo właściwe dla poszczególnych kategorii stosunków, a jedynie stanowią ogólną podstawę 


\subsection{Pochodzenie norm, do których odwołuje się art. 30}

W związku z brzmieniem pkt. 54 preambuły, mogą nasuwać się wątpliwości co do znaczenia pochodzenia przepisów imperatywnych, o których mowa. Treść samego art. 30 nie pozostawia jednak wątpliwości, że chodzi tu o przepisy prawa państwa położenia poszczególnych składników spadku bez względu na jego przynależność (bądź jej brak) do Unii Europejskiej ${ }^{27}$. Błędne sformułowanie preambuły wynika natomiast jedynie $\mathrm{z}$ niedostrzeżenia różnic $\mathrm{w}$ sposobie redakcji przepisu między projektem a ostatecznym tekstem rozporządzenia.

\subsection{Konkluzja}

Reasumując, stwierdzić należy, że art. 30 rozporządzenia jest podstawa dopuszczenia do głosu, przy ocenie dziedziczenia poszczególnych składników spadku, niezależnie od (obok lub zamiast) postanowień statutu spadkowego, także wymuszających swoje zastosowanie przepisów prawa państwa ich położenia, które ze względów ekonomicznych, rodzinnych lub społecznych wprowadzają odrębności w odniesieniu do dziedziczenia danego przedmiotu, a będąc wyrazem ochrony szczególnie ważnych interesów publicznych państwa ich pochodzenia, znajduja na mocy jego prawa zastosowanie poza ogólnym mechanizmem kolizyjnoprawnym. Nie ma natomiast znaczenia, czy chodzi o regulacje wchodzace w skład legis fori, czy należące do porządku prawnego państwa trzeciego. Wydaje się natomiast, że ewentualne regulacje o takich cechach, przynależące do statutu spadkowego, o ile w ogóle dany stan faktyczny będzie mieścił się $\mathrm{w}$ sferze ich zainteresowania, znajdą zastosowanie jako miarodajny dla przedmiotu rozstrzygnięcia fragment legis successionis, a więc $\mathrm{w}$ ramach ogólnego mechanizmu kolizyjnoprawnego ${ }^{28}$.

dopuszczenia do głosu takich postanowień pochodzących z poszczególnych, krajowych porządków prawnych, w których ucieleśniona została „wola” zastosowania niezależnie od prawa właściwego w normalnym toku rzeczy - R. Freitag: Art. 9 Rom I-VO, Art. 16 Rom II - VO als Superkollisionsnormen des Internationalen Schuldrechts? - Gedanken zum Verhältnis zwischen internen und externen Lücken des EuIPR. „Praxis des Internationalen Privat- und Verfahrensrechts" 2016, Nr. 5, s. 420.

${ }^{27}$ A. Dutta, in: Münchener..., s. 1571; M.A. Zachariasiewicz: Przepisy wymuszajace..., s. 330 .

${ }^{28}$ A. Dutta, in: Münchener..., s. 1572. Odmiennie jednak — na tle polskich przepisów o zarządzie sukcesyjnym przedsiębiorstwa osoby fizycznej - M. Pazdan: Zarząd sukcesyjny..., s. 74 . 


\subsection{Przykłady regulacji spełniających kryteria z art. 30}

Wśród regulacji prawnych, które - w zależności od decyzji danego ustawodawcy - moga spełniać kryteria, o których mowa w art. 30 rozporządzenia, warto wymienić zwłaszcza:

- szczególne przepisy o dziedziczeniu gospodarstw rolnych bądź ich niektórych kategorii ${ }^{29}$, które wyłączaja (w zakresie regulowanych nimi spraw) tego rodzaju składniki spadku spod ogólnego porządku dziedziczenia, poddając je regulacji szczególnej, w celu zapobieżenia ich podziałowi, zachowania ich zdolności produkcyjnej lub pozostawienia w rękach osób dysponujacych określonymi kwalifikacjami;

- występujące $\mathrm{w}$ niektórych państwach ${ }^{30}$ — przepisy szczególne odnoszące się do nabycia mortis causa praw do lokali mieszkalnych służących zaspokojeniu potrzeb rodziny ${ }^{31}$, o ile w świetle miarodajnych norm legis sitae nabycie to zachowuje charakter dziedziczenia, nie jest natomiast - mieszczącym się w zakresie zastosowania statutu rzeczowego lub kontraktowego (zależnie od charakteru danego prawa podmiotowego mającego za przedmiot lokal) — odrębnym reżimem sukcesji syngularnej;

- ograniczenia w dziedziczeniu nieruchomości (bądź niektórych ich kategorii) przez cudzoziemców, jak ma to miejsce w przypadku polskiej ustawy z 24.03.1920 r. o nabywaniu nieruchomości przez cudzoziemców $^{32}$. Służą one realizacji społecznie i ekonomicznie doniosłego celu: zapobieganiu przechodzenia najistotniejszych składników majątku w ręce osób nieposiadających obywatelstwa danego państwa, a ze względu na swe znaczenie $\mathrm{z}$ punktu widzenia ochrony jego interesów publicznych, obejmują swoim zasięgiem wszystkie nieruchomości (bądź wyróżnione ich kategorie) położone na jego obszarze.

W nauce polskiej sformułowano ostatnio postulat ${ }^{33}$, by przez pryzmat art. 30 rozporządzenia postrzegać zasięg przestrzenny przepisów ustawy z 5.07.2018 r. o zarzadzie sukcesyjnym przedsiębiorstwa osoby fizycznej ${ }^{34}$.

${ }^{29}$ M. Stürner: Die Bedeutung des ordre public in der EuErbVO. „Zeitschrift für Gemeinschaftsprivatrecht" 2014, Nr. 6, s. 319.

${ }^{30}$ J. Pazdan: Ku jednolitemu międzynarodowemu prawu spadkowemu. „Rejent” 2005, nr 3, s. 13.

${ }^{31}$ A. Dutta, in: Münchener..., s. 1571.

${ }^{32}$ M.A. Zachariasiewicz: Przepisy wymuszajace..., s. 331.

${ }^{33}$ M. Pazdan: Zarzad sukcesyjny..., s. 74.

${ }^{34}$ Dz.U. 2018, poz. 1629 [dalej: ZarządSukcU]. 
Jak wskazuje M. Pazdan, nie stoi temu na przeszkodzie dobrowolność $\mathrm{w}$ korzystaniu $\mathrm{z}$ instrumentu zarządu sukcesyjnego ${ }^{35}$.

Pomimo formułowanych $\mathrm{w}$ tej mierze zastrzeżen ${ }^{36}$, przepisy wskazanej ustawy zdają się posiadać wszystkie cechy, do których odwołuje się norma $\mathrm{z}$ art. 30 .

I tak, gdy chodzi o kryterium przedmiotu ich regulacji, to - jak wskazuje art. 1 ZarządSukcU - koncentrują się one na uregulowaniu zasad tymczasowego zarządzania przedsiębiorstwem po śmierci przedsiębiorcy, działającego w oparciu o wpis do Centralnej Ewidencji i Informacji o Działalności Gospodarczej (CEIDG) oraz kontynuowania działalności gospodarczej prowadzonej z jego wykorzystaniem. Przepisy te wprawdzie nie wprowadzaja ograniczeń dotyczących dziedziczenia przedsiębiorstwa w spadku, ale rzutujac na zarząd nim, bezpośrednio dotykaja materii należącej do zakresu właściwości legis successionis stosownie do art. 23 ust. 2 lit. f rozporządzenia ${ }^{37}$. Nie powinno więc budzić wątpliwości, że mamy tu do czynienia z regulacją wpływająca na dziedziczenie objętego nią składnika spadku w rozumieniu art. 30 rozporządzenia.

Za spełnione uznać należy także kryterium szczególnego charakteru prawnego regulacji, o której mowa. Określone jej przepisami szczególne zasady tymczasowego zarządu nie rozciągają się na całość spadku po zmarłym. Odnoszą się one jedynie do jego wybranego składnika, jakim jest przedsiębiorstwo w spadku, poddając go - gdy chodzi o zarząd odrębnemu reżimowi prawnemu.

Nie pozostawia też wątpliwości, że za szczególnym uregulowaniem zasad zarządu tym właśnie składnikiem spadku stoją istotne wartości ekonomiczne, rodzinne oraz społeczne, natomiast sama ustawa jest przejawem realizacji szczególnie ważnych interesów publicznych państwa. Świadczy o tym nie tylko jej treść, ale i motywy wyartykułowane w pkt. I uzasadnienia do jej projektu, gdzie przedsiębiorstwo postrzegane jest jako dobro prawne o istotnej wartości społecznej, a dążenie do zapewnienia warunków do zachowania ciagłości jego funkcjonowania po śmierci przedsiębiorcy ma na względzie nie tylko interes jego następców prawnych, lecz również ochronę praw osób trzecich oraz interes publiczny.

${ }^{35}$ M. Pazdan: Zarzqd sukcesyjny..., s. 74. Por. także: G. Contaldi, in: The EU Succession Regulation. A Commentary. Eds. A.L. Calvo Caravaca, A. Davi, H.P. Mansel. Cambridge 2016, s. 438, którego zdaniem art. 30 może być podstawą dopuszczenia do głosu również takich przepisów, których zastosowanie nie zawsze będzie obowiązkowe na poziomie krajowym.

${ }^{36}$ Por. J. Górecki: Prawo właściwe dla czynności zwiazanych z zarzqdem sukcesyjnym - referat wygłoszony podczas Ogólnopolskiej Konferencji Naukowej nt. Zarzqd sukcesyjny przedsiębiorstwem osoby fizycznej, zorganizowanej w Warszawie, 7.06.2019 r.

${ }^{37}$ Por. także motyw 42 preambuły do rozporządzenia. 
Cele te $\mathrm{w}$ powiązaniu z brzmieniem art. 1 ZarządSukcU zdają się równocześnie wskazywać na tkwiąca $\mathrm{w}$ przepisach, o których mowa, wolę zastosowania $\mathrm{w}$ odniesieniu do wszystkich przedsiębiorstw $\mathrm{w}$ spadku objętych zakresem regulacji ustawy bez względu na prawo właściwe dla dziedziczenia, tj. niezależnie od tego, czy statutem spadkowym po zmarłym przedsiębiorcy działającym w oparciu o wpis do CEIDG jest prawo polskie, czy też prawo innego państwa ${ }^{38}$.

Ocenie takiej nie sprzeciwia się - w czym zgadzam się z M. Pazdanem - fakt, że skorzystanie z instytucji zarządu sukcesyjnego pozostawiono woli osób uprawnionych, skoro gdy tylko dojdzie do jego ustanowienia, determinuje on dalszy sposób sprawowania zarządu przedsiębiorstwem w spadku oraz kontynuacji działalności gospodarczej z jego wykorzystaniem.

Przy ocenie przepisów ustawy o zarządzie sukcesyjnym pod katem art. 30 rozporządzenia, wątpliwości może nasuwać natomiast sposób podejścia w ich treści do kwestii lokalizacji objętych zarządem składników spadku. Otóż art. $1 \mathrm{w}$ zw. z art. 2 ust. 1 ZarządSukcU, wyznaczając zakres zastosowania ustawy, nie odwołuje się wprost do kryterium miejsca położenia przedsiębiorstwa w spadku, lecz do jego przynależności do majatku przedsiębiorcy, działajacego w oparciu o wpis do CEIDG - szczególnego systemu (rejestru podmiotowego) ewidencjonujaccego podejmowanie oraz prowadzenie działalności gospodarczej przez osoby fizyczne na terytorium Polski. Tymczasem nie można wykluczyć, że w skład przedsiębiorstwa w spadku po takiej osobie, poza składnikami położonymi na terenie naszego kraju, moga wchodzić również dobra znajdujące się za granica bądź przemieszczane $\mathrm{w}$ zależności od potrzeb między terytoriami różnych państw. Ścisły związek między wykonywaną w oparciu o wpis do CEIDG działalnościa przedsiębiorcy a stanowiacym dla niej bazę materialna przedsiębiorstwem pozwala jednak - jak się wydaje — przyjąć, iż nawet jeśli niektóre spośród jego składników znajdują się w innym państwie, to jako całość jest ono zlokalizowane tu, gdzie prowadzony jest rejestr. Przy takim założeniu można zgodzić się ze stwierdzeniem, że ustawa odnosi się do przedsiębiorstw w spadku położonych w Polsce ${ }^{39}$.

Przyjmując, że postanowienia ustawy zaliczaja się do kategorii przepisów, o których mowa w art. 30 rozporządzenia, powinny one znaleźć zastosowanie $\mathrm{w}$ odniesieniu do wszystkich objętych zakresem jej regulacji przedsiębiorstw w spadku, bez względu na to, czy statutem spadkowym jest prawo polskie oraz niezależnie od tego, w którym państwie

\footnotetext{
${ }^{38}$ M. Pazdan: Zarzad sukcesyjny..., s. 73 i 74.

${ }^{39}$ Ibidem, s. 73.
} 
członkowskim rozpatrywana jest sprawa spadkowa po zmarłym przedsiębiorcy ${ }^{40}$.

Przedstawione powyżej zestawienie obejmuje jedynie przykłady przepisów mogacych spełniać kryteria, o których mowa w art. 30 rozporządzenia. Oceniajac pod tym katem inne uregulowania obowiązujące w państwie położenia danego składnika spadku należy zawsze pamiętać, że art. 30 rozporządzenia, jako wyjątek od zasady kolizyjnoprawnej jedności spadku, podlega interpretacji ścisłej (pkt 54 motywów rozporządzenia). Określonych tam kryteriów nie spełniają m.in. występujace $\mathrm{w}$ wielu systemach prawnych szczególne normy kolizyjne, poddające dziedziczenie nieruchomości właściwości innego prawa niż ogólny statut spadkowy, jak również przepisy przewidujące wyższy od znanego legi successionis udział obowiazkowy albo zachowek ${ }^{41}$.

\section{Skutki zastosowania art. 30 rozporządzenia spadkowego}

Kolejnym zagadnieniem wymagającym rozstrzygnięcia na tle art. 30 rozporządzenia jest wpływ objętych jego treścią przepisów na rozstrzygnięcie sprawy spadkowej. Należy zadać w pierwszej kolejności pytanie, czy stwierdzenie istnienia $\mathrm{w}$ odniesieniu do danego składnika spadku regulacji prawnej o wskazanych tam cechach obliguje sąd (z zastrzeżeniem odmiennych wniosków, do jakich w konkretnym wypadku może prowadzić klauzula porządku publicznego) do jej zastosowania, czy też dysponuje on swoboda podejmowania decyzji w tym względzie. Do tego rodzaju rozważań skłania różnica między brzmieniem art. 30 rozporządzenia spadkowego, a jego odpowiednikami znanymi z innych aktów prawnych zawierajacych regulację prawa prywatnego międzynarodowego. Otóż zarówno art. 7 Konwencji rzymskiej ${ }^{42}$, jak i art. 9 zastępującego ją rozporządzenia Rzym I wskazują w odniesieniu do przepisów wymuszających swoje zastosowanie legis fori, na nienaruszanie ich stosowania ${ }^{43}$ oraz na możność przyznania skuteczności tego rodzaju normom państwa trzeciego ${ }^{44}$. Podobna formuła posługuje się także art. 16

\footnotetext{
${ }^{40}$ Ibidem, s. 74 .

${ }^{41}$ A. Dutta, in: Münchener..., s. 1571; M. Stürner: Die Bedeutung..., s. 319.

${ }^{42}$ Konwencja rzymska z dnia 19.06 .1980 r. o prawie właściwym dla zobowiąań umownych (Dz.Urz. C 334).

${ }^{43}$ Art. 7 ust. 2 Konwencji rzymskiej oraz art. 9 ust. 2 rozporządzenia Rzym I.

${ }^{44}$ Art. 7 ust. 1 Konwencji rzymskiej oraz art. 9 ust. 3 rozporządzenia Rzym I.
} 
rozporządzenia Rzym II, gdy chodzi o wymuszające swoje zastosowanie przepisy państwa siedziby sądu oraz, będąca pierwowzorem rozwiązania przyjętego w rozporządzeniu spadkowym, norma z art. 15 Konwencji haskiej z 1989 r. - w odniesieniu do imperatywnych norm państwa lokalizacji poszczególnych składników spadku ${ }^{45}$.

Taka metoda regulacji jest charakterystyczna dla określenia miary skuteczności przepisów wymuszających swoje zastosowanie ${ }^{46}$. Nie nakłada ona na sądy innego państwa obowiązku ich zastosowania, pozostawiając decyzję o tym, czy w konkretnym przypadku dojdą one do głosu sędziemu, który powinien wziąc pod uwagę ich charakter i cel, a także skutki ich zastosowania lub ewentualnego pominięcia w ustalonym stanie faktycznym ${ }^{47}$. Należy również każdorazowo rozstrzygnąć, czy takie zastosowanie byłoby uzasadnione $\mathrm{z}$ międzynarodowego punktu widzenia ${ }^{48}$. Nie oznacza to jednak zupełnej dowolności w postępowaniu, bowiem zastosowanie bądź pominięcie przez sąd obcego przepisu wymuszajacego swoje zastosowanie podlega kontroli realizowanej w trybie środków zaskarżenia. Podejście takie - w przypadku rozporządzeń Rzym I i Rzym II - znajduje dodatkowe potwierdzenie w odpowiednich punktach ich preambuł. Mowa tam o przyznaniu sądom państw członkowskich jedynie możliwości odwoływania się w wyjątkowych okolicznościach, do stosowania wyjątków opartych na przepisach wymuszających swoje zastosowanie $^{49}$.

Pod tym względem metoda regulacji przyjęta w rozporządzeniu spadkowym wydaje się przedstawiać odmiennie. Artykuł 30, w odniesieniu do przepisów imperatywnych posiadających wskazane tam cechy, nie wspomina o nienaruszaniu ich stosowania ani o możliwości przyznania

${ }^{45}$ The law applicable under the Convention does not affect the application [...].

${ }^{46} \mathrm{~W}$ literaturze podkreśla się, że pod pojęciem przepisów wymuszających swoje zastosowanie rozumieć trzeba nie tyle jakąś wyodrębniona, szczególną kategorię norm o charakterze „policyjnym”, ile pojedyncze przepisy, „punktowo” chroniące szczególnie ważne interesy publiczne państwa ich pochodzenia, posiadajace jedynie potencjalnie wymuszający charakter, których zastosowanie bądź odmowa zastosowania stanowi zawsze indywidualną decyzję sądu, opartą na analizie ich natury i celu, chronionych nimi interesów, ale podejmowana zawsze w układzie okoliczności konkretnego przypadku — por. M.A. Zachariasiewicz, w: „System Prawa Handlowego”. T. 9: Międzynarodowe prawo handlowe. Red. W. Popiołek. Warszawa 2013, s. 263 oraz cytowaną tam literaturę.

${ }^{47}$ Tak na tle rozporządzenia Rzym I O. Lando, P.A. Nielsen: The Rome I Regulation. „Common Market Law Review” 2008, s. 1721.

${ }^{48}$ Tak na tle rozporządzenia Rzym I Ł. Żarnowiec, w: Komentarz do rozporzqdzenia Parlamentu Europejskiego i Rady (WE) nr 593/2008 w sprawie prawa wtaściwego dla zobowiazań umownych (Rzym I). M. Zachariasiewicz, Ł. Żarnowiec, M.A. Zachariasiewicz, M. Kropka, M. Jagielska, Lex/el. 2013, art. 9.

${ }^{49}$ Pkt 32 preambuły do rozporządzenia Rzym II oraz pkt 37 preambuły do rozporzadzenia Rzym I. 
im skutku, lecz wskazuje, że mają one zastosowanie do dziedziczenia ${ }^{50}$. Unormowanie to uzupełnia treść motywu 54 preambuły do rozporzadzenia, w którym zawarto deklarację zapewnienia stosowania szczególnych uregulowań państw lokalizacji niektórych kategorii składników majątku, które ze względów ekonomicznych, rodzinnych lub społecznych nakładaja ograniczenia dotyczące ich dziedziczenia lub wpływające na ich dziedziczenie. Wykładnia językowa prowadzi zatem do wniosku, że art. 30 nie pozostawia sądowi orzekającemu swobody decyzji co do zastosowania bądź pominięcia norm prawnych państw położenia poszczególnych składników spadku o wskazanych tam cechach (o ile oczywiście one same „chcą” znaleźć w danym wypadku zastosowanie), lecz - co do zasady - przewiduje ich zastosowanie obok lub zamiast miarodajnych postanowień legis successionis ${ }^{51}$.

Nie oznacza to oczywiście całkowitego związania sądu. Podobnie jak ma to miejsce $\mathrm{w}$ przypadku innych przepisów prawa wskazanego za pośrednictwem norm kolizyjnych rozporządzenia, powinien on każdorazowo dokonać oceny zgodności zastosowania danej normy merytorycznej $\mathrm{z}$ własnym porzadkiem publicznym ${ }^{52}$.

Wnioski, do jakich prowadzi wykładnia językowa, pozostają w zgodzie także z celami rozporządzenia. Podejście takie pozytywnie wpływa bowiem na uznanie lub wykonanie orzeczeń bądź innych dokumentów, wydanych w oparciu o prawo wskazane za pośrednictwem przepisów rozporządzenia, w państwach położenia poszczególnych składników spadku, także niebędących państwami członkowskimi UE.

Prezentowany powyżej pogląd nie oznacza, by art. 30 rozporządzenia miał stanowić - w razie ziszczenia się opisanych w jego treści przesłanek — podstawę wyłączenia danego składnika spadku spod właściwości ogólnego statutu spadkowego i poddania oceny jego losów w całości mia-

${ }^{50}$ Analogicznie sformułowane zostały także inne wersje językowe art. 30 rozporządzenia, co pozwala wykluczyć nierzadko występujący w przypadku polskojęzycznych wersji aktów prawa unijnego element błędu w tłumaczeniu — por. „finden auf die Rechtsnachfolge von Todes wegen Anwendung, soweit sie nach dem Recht dieses Staates unabhängig von dem auf die Rechtsnachfolge von Todes wegen anzuwendenden Recht anzuwenden sind” (w wersji niemieckiej), „those special rules shall apply to the succession” (w wersji angielskiej).

${ }^{51}$ A. Dutta, in: Münchener..., s. 1571; G. Contaldi, in: The EU Succession ..., s. 439; Ł. Żarnowiec: Wptyw statutu rzeczowego..., s. 324. Odmiennie jednak M.A. Zachariasiewicz, której zdaniem, przepisy te wchodzą w grę wówczas, gdyby rezultat zastosowania statutu spadkowego okazał się niemożliwy do pogodzenia z racjami i interesami, których ochronie służą - M.A. Zachariasiewicz: Przepisy wymuszajace..., s. 335 .

${ }^{52}$ M. Mataczyński: Przepisy ograniczajace..., s. 298. 
rodajnym dla dziedziczenia postanowieniom legis sitae ${ }^{53}$. Chodzi tu o zastosowanie jedynie miarodajnych (wskazanych w art. 30 rozporządzenia) przepisów szczególnych państwa położenia danego składnika majątku. Dojdą one do głosu obok (a jedynie w niezbędnym zakresie zamiast) miarodajnych postanowień legis successionis, co w konkretnym przypadku może oznaczać konieczność dostosowania rozwiązań wynikających z obu systemów prawnych ${ }^{54}$.

\section{Znaczenie przepisów wymuszających swoje zastosowanie niespełniających przesłanek z art. 30}

Istotnym problemem powstającym na tle art. 30 rozporządzenia jest wpływ na rozstrzyganie spraw spadkowych przepisów wymuszających swoje zastosowanie nieobjętych regulacją tego przepisu. Chodzi tu o występujące $\mathrm{w}$ systemach prawnych wielu państw normy, znajdujące zastosowanie do spraw spadkowych, którym - ze względu na tkwiący w nich pierwiastek interesu publicznego - przypisuje się moc ich zastosowania niezależnie od postanowień legis successionis, które jednak nie koncentruja się na szczególnej regulacji dziedziczenia wybranych składników spadku położonych na obszarze danego państwa. Powstaje w związku z tym pytanie, czy w art. 30 rozporządzenia należy upatrywać dorozumianego wyłączenia zastosowania tego rodzaju regulacji, czy też uznać, że rozporządzenie kwestii tej nie rozstrzyga.

Poruszony problem niejest zupełnie nowy. Podobne wateliwości pojawiają się na tle przepisów rozporządzenia Rzym II oraz rozporządzenia Rzym I.

I tak, poświęcony przepisom wymuszającym swoje zastosowanie w obszarze zobowiązań pozaumownych art. 16 rozporządzenia Rzym II, wypowiada się wyłącznie co do znaczenia tego rodzaju norm państwa forum. Pomimo to uznaje się, że brak regulacji poświęconej przepisom

${ }^{53}$ Odmiennie - moim zdaniem nietrafnie - A. Köhler, in: Internationales Erbrecht..., s. 132, który wskazuje, że w tego rodzaju przypadkach porządek dziedziczenia w odniesieniu do wymienionych w art. 30 składników spadku, objętych szczególna regulacja, podlega legi rei sitae. Podstaw do takiego wniosku nie dostarczaja jednak brzmienie i funkcje art. 30. Norma ta przewiduje zastosowanie - niezależnie od ogólnej legis successionis - jedynie miarodajnych, szczególnych przepisów nakładających ograniczenia lub wpływających na dziedziczenie objętych ich regulacją składników majątku, nie stwarza natomiast podstaw do zastąpienia, gdy chodzi o ocenę ich dziedziczenia, normalnego statutu spadkowego, prawem państwa ich położenia.

${ }^{54}$ M.A. Zachariasiewicz: Przepisy wymuszajace..., s. 335. 
koniecznego zastosowania państwa trzeciego nie oznacza zakazu ich stosowania, a jedynie przenosi zadanie wypracowania podstawy ich dopuszczenia do głosu na płaszczyznę zasad ogólnych prawa prywatnego międzynarodowego ${ }^{55}$.

Inaczej natomiast kwestia ta się przedstawia, gdy chodzi o rozporządzenie Rzym I. Otóż, w odniesieniu do przepisów koniecznego zastosowania państwa trzeciego, jego art. 9 ust. 3 pozwala przyznać skuteczność jedynie normom państwa, w którym ma nastąpić lub nastąpiło wykonanie zobowiązań wynikajacych z umowy, i to jedynie w zakresie, w jakim przepisy te powoduja, że wykonanie umowy jest niezgodne z prawem. Wnioski wypływajace $\mathrm{z}$ toku prac nad projektem tego aktu prawnego, zmiana względem obowiązujacego uprzednio art. 7 ust. 1 Konwencji rzymskiej, przede wszystkim jednak samo brzmienie przepisu, pozwalającego przyznać skuteczność wyłącznie ściśle określonej kategorii norm wymuszających swoje zastosowanie, przeważyły na rzecz stanowiska upatrujacego w art. 9 ust. 3 rozporządzenia Rzym I regulacji wyczerpującej, wyłączajacej zastosowanie innych przepisów imperatywnych państwa trzeciego ${ }^{56}$. Taki też punkt widzenia wyraził TSUE ${ }^{57}$.

${ }^{55}$ S. Leible, M. Lehmann: Die neue Verordnung über das auf außervertragliche Schuldverhältnisse anzuwendende Recht (,Rom II”). RIW 2007, Nr. 10, s. 726; S. Leible: Rechtswahl im IPR der außervertraglichen Schuldverthältnisse nach der Rom II Verordnung. RIW 2008, Nr. 5, s. 263; P. Mankowski: Das Neue Internationale Kartellrecht des Art. 6 Abs. 3 der Rom II - Verordnung. RIW 2007, Nr. 10, s. 182; J. v. Hein: Europäisches Internationales Deliktsrecht nach der Rom II - Verordnung. „Zeitschrift für Europäisches Privatrecht" 2009, Nr. 1, s. 24; G. Hohloch, in: Erman, Handkommentar..., s. 6795. Odmiennie natomiast: G. Wagner: Die neue Rom II - Verordnung. IPRax 2008, Nr. 1, s. 15; H. Ofner: Die Rom II - Verordnung - Neues Internationales Privatrecht für außervertragliche Schuldverhältnisse in der Europäischen Union. „Zeitschrift für Europarecht, internationals Privatrecht und Rechtsvergleichung, wcześniej: Zeitschrift für Rechtsvergleichung" 2008, Nr. 1, s. 23; R. Plender, M. Wilderspin: The European Private International Law..., s. 743; A. Nowicka: Prawo właściwe dla zobowiazań wynikajacych z czynów niedozwolonych $w$ świetle przepisów rozporzqdzenia nr 864/2007. „Prace Instytutu Prawa Własności Intelektualnej” 2007, nr 100, s. 333; D. Jakob, P. Picht, in: Europäisches Zivilprozess- und Kollisionsrecht..., s. 968-969.

${ }^{56}$ D. Martiny, in: Münchener Kommentar zum Bürgerlichen Gesetzbuch. Bd. 10: Internationales Privatrecht, Rom I - Verordnung, Rom II - Verordnung, Einführungsgesetz zum Bürgerlichen Gesetzbuche (art. 1-24). Hrsg. H.J. Sonnenberger. München 2010, s. 836; U. Magnus, in: J. von Staudingers Kommentar zum Bürgerlichen Gesetzbuch mit Einführungsgesetz und Nebengesetzen. Einführungsgesetz zum Bürgerlichen Gesetzbuche/IPR. Einleitung zur Rom I-VO; Art. 1-10 Rom I-VO (Internationales Vertragsrecht). Hrsg. U. Magnus. Berlin 2011, s. 672; O. Lando, P.A. Nielsen: The Rome I..., s. 1722; Ł. Żarnowiec, w: Komentarz..., art. 9.

${ }^{57}$ Orz. TSUE z 18.10.2016 r. w sprawie C-135/15 Republika Grecka przeciwko Grigoriosowi Nikiforidisowi, dostępny na stronie internetowej http://curia.europa.eu/juris/ documents.jsf?num=C-135/15\# [Data dostępu: 12.09.2019 r.]. 
$\mathrm{Na}$ tym tle art. 30 rozporządzenia spadkowego, jawi się jednak jako regulacja specyficzna. Inaczej niż w tamtych przypadkach nie wprowadza on rozróżnienia między przepisami wymuszającymi swoje zastosowanie państwa trzeciego, a tego rodzaju normami forum. Decydujace znaczenie ma natomiast to, czy należą one do prawa państwa położenia składników spadku, modyfikując w stosunku do nich ogólne reguły dziedziczenia, niezależnie, czy jest to państwo siedziby sądu, czy inne ${ }^{58}$. Ponadto, jak podniesiono już wcześniej, istota przyjętego tam rozwiązania jest (jak się wydaje) nakaz zastosowania wskazanych tam norm imperatywnych, a nie jedynie stworzenie podstawy dla decydowania przez sąd o ich dopuszczeniu do głosu w okolicznościach konkretnej sprawy.

Pomimo to art. 30 rozporządzenia bywa postrzegany jako wyczerpujace unormowanie, gdy chodzi o podstawę dopuszczenia do głosu $\mathrm{w}$ sprawach spadkowych przepisów imperatywnych spoza legis successionis $^{59}$, przy czym niektórzy zwolennicy takiego podejścia skłonni sa - z różnym zreszta uzasadnieniem - dopuścić wyjątek na rzecz tego rodzaju norm, należących do systemu prawnego państwa forum ${ }^{60}$. Stanowisko przeciwne stosowaniu przepisów wymuszajacych swoje zastosowanie (bez względu na ich pochodzenie) poza wyraźną regulacją art. 30 obecne jest także w nauce polskiej ${ }^{61}$. Jednak w ocenie innych, $\mathrm{w}$ art. 30 nie należy upatrywać zakazu dopuszczenia do głosu, w sferze stosunków prawnospadkowych przepisów wymuszających swoje zastosowanie niespełniajacych opisanych w jego treści przesłanek. Podstaw ich zastosowania trzeba by jednak poszukiwać poza zakresem art. 30 rozporządzenia - wśród zasad ogólnych prawa prywatnego międzynarodowego ${ }^{62}$. W nauce polskiej podobny punkt widzenia zaprezentowała M.A. Zachariasiewicz, ograniczając go jednak do przepisów odnoszacych się do aspektów dziedziczenia innych niż wymienione w art. 30 . Jak wskazuje, milczenia ustawodawcy nie sposób utożsamiać z wyraź-

${ }^{58}$ G. Contaldi, in: The EU Succession..., s. 439.

${ }^{59}$ K. Kroll-Ludwigs: Die Rolle der Parteiautonomie im europäischen Kollisionsrecht. Tübingen 2013, s. 563. Autorka podnosi, że prawodawca unijny - wbrew propozycjom Instytutu Maxa Plancka — ostatecznie zdecydował się nie wprowadzać do rozporządzenia spadkowego konstrukcji przepisów wymuszających swoje zastosowanie.

${ }^{60}$ A. Dutta, in: Münchener..., s. 1571-1572. Tak też — wskazując jednak jako podstawę ich dopuszczenia do głosu klauzulę porządku publicznego (art. 35) - G. Contaldi, in: The EU Succession..., s. 439-440.

${ }^{61}$ A. Wysocka-Bar: Prawo właściwe dla dziedziczenia wedtug unijnego rozporzqdzenia dotyczqcego spraw spadkowych. KPP 2012, nr 4, s. 921-922; Eadem: Wybór prawa w międzynarodowym prawie spadkowym. Warszawa 2013, s. 346; M. Mataczyński: Przepisy ograniczajace..., s. 300.

${ }^{62}$ A. Köhler, in: Internationales Erbrecht..., s. 133, 137-138. 
nym wyłączeniem terytorialno - przedmiotowym, jak ma to miejsce w przypadku art. 9 ust. 3 Rzymu $\mathrm{I}^{63}$.

Pomimo wątpliwości, jakie nasuwa brzmienie art. 30 rozporządzenia, wiele przemawia za słusznością ostatniego z zaprezentowanych powyżej poglądów, chociaż definitywne rozstrzygnięcie tej kwestii może przynieść dopiero stosowne orzeczenie TSUE. Otóż w treści analizowanego przepisu trudno dopatrzyć się przeszkód w dopuszczeniu do głosu innych niż tam wskazane przepisów wymuszających swoje zastosowanie, zarówno wchodzacych w skład legis fori, jak i pochodzacych z państwa trzeciego, z którego obszarem sprawa wykazuje dostatecznie silny związek. Inaczej niż w przypadku art. 9 ust. 3 rozporządzenia Rzym I, art. 30 rozporządzenia spadkowego, odnosi się wyłącznie do norm imperatywnych regulujacych wybrany aspekt spraw związanych $\mathrm{z}$ dziedziczeniem, tj. modyfikujących ogólne reguły dziedziczenia w odniesieniu do niektórych składników spadku. Ponadto, inaczej niż rozporządzenie Rzym I, kreuje nie tyle możliwość, ile raczej powinność ich stosowania. Z faktu zawarcia w rozporządzeniu nakazu dopuszczenia do głosu wyraźnie określonej kategorii przepisów wymuszających swoje zastosowanie nie należy wyprowadzać zakazu stosowania innych unormowań o takim charakterze. W kwestii tej — jak się wydaje — rozporządzenie nie zajmuje stanowiska, co pozwala uznać ją za nieuregulowaną.

Pominięcie unormowania odnoszącego się do przepisów imperatywnych, niewymienionych w art. 30 rozporządzenia, przenosi zadanie wypracowania podstawy ich ewentualnego zastosowania na inna płaszczyznę. Nie widzę przeszkód, w ich dopuszczeniu do głosu — tak jak dotychczas — na podstawie szczególnych (stanowionych bądź niepisanych) norm kolizyjnych forum - w przypadku polskiego sądu: art. 8 PrPrywM z 2011. Ewentualne zastosowanie tego rodzaju uregulowań pozostaje więc kwestią decyzji sądu, podejmowanej w układzie okoliczności konkretnego przypadku. Konkluzja ta odnosi się zarówno do przepisów wymuszających swoje zastosowanie wchodzacych w skład systemu prawnego państwa siedziby sądu, jak i państwa trzeciego ${ }^{64}$.

Za podejściem takim przemawia jeszcze jeden argument. Otóż rozporządzenie spadkowe w odróżnieniu od innych unijnych aktów ujednoliconego prawa prywatnego międzynarodowego, odnosząc się do przepisów wymuszajacych swoje zastosowanie nie wyodrębnia tego rodzaju norm wchodzących w skład legis fori. Na płaszczyźnie jego art. 30, sytuacja przepisów szczególnych państwa siedziby sądu nie różni się niczym od

${ }^{63}$ M.A. Zachariasiewicz, w: Prawo prywatne międzynarodowe. Komentarz. Red. M. Pazdan. Warszawa 2018, s. 1234.

${ }^{64}$ Ł. Żarnowiec: Wptyw statutu rzeczowego..., s. 330-331. 
tego rodzaju norm państwa trzeciego. Zatem negując dopuszczalność sięgnięcia do przepisów imperatywnych innych niż wskazane w art. 30 rozporządzenia, należałoby tę ocenę odnieść także do tego rodzaju norm legis fori, co trudno zaaprobować.

Obawy formułowane wobec rozwiązania umożliwiającego uwzględnianie, poza zakresem normy z art. 30 rozporządzenia, przepisów wymuszających swoje zastosowanie państwa trzeciego nie przekonują. Za idea spójności koncepcji przepisów wymuszajacych swoje zastosowanie przemawiaja natomiast istotne argumenty tj. zwiększenie szans na osiągnięcie międzynarodowej harmonii rozstrzygnięć oraz - co z punktu widzenia celów stawianych przed rozporządzeniem spadkowym szczególnie ważne - zapewnienie możliwie najszerszej skuteczności oraz wykonalności orzeczeń sądów państw członkowskich w objętych jego regulacją sprawach $^{65}$.

Przeszkód w dopuszczeniu do głosu przepisów wymuszających swoje zastosowanie poza regulacja art. 30 rozporządzenia nie dostrzegam także w treści pkt 54 preambuły. Wprawdzie w nawiązaniu do idei jedności statutu spadkowego podkreśla się tam wyjątkowy charakter i konieczność ścisłej interpretacji art. 30, równocześnie jednak jego brzmienie wskazuje, iż dotyczy to pojmowania „szczególnych uregulowań nakładających ograniczenia dotyczące dziedziczenia niektórych składników majątku lub wpływających na ich dziedziczenie" (a więc tych, którym należy zapewnić stosowanie niezależnie od prawa w normalnym toku rzeczy właściwego dla danego stosunku) nie zaś przepisów wymuszających swoje zastosowanie jako takich.

Podsumowując w art. 30 rozporządzenia spadkowego upatrywałbym jedynie, ograniczonego do (pojmowanych ściśle) regulacji o wskazanych tam cechach, nakazu stosowania przepisów imperatywnych (państwa trzeciego lub państwa sądu). Odmienną sprawa jest natomiast dopuszczenie do głosu innych niż wymienione w art. 30 przepisów wymuszajacych swoje zastosowanie, należących czy to do państwa siedziby sądu, czy to państwa trzeciego. Artykuł 30 nie sprzeciwia się - jak sądzę stosowaniu w konkretnych przypadkach, nieznanych statutowi spadkowemu, a występujących w systemie prawnym innego państwa, z którym sprawa spadkowa wykazuje dostatecznie silny związek (w grę wchodzi tu zwłaszcza prawo państwa siedziby sądu, ale też np. lokalizacji spadku), szczególnych zakazów testowania czy negatywnych przesłanek dopuszczalności dziedziczenia, odnoszących się np. do personelu domu opieki, spowiedników, lekarzy itd., o ile tylko służą one realizacji szczególnie doniosłych wartości porządku publicznego państwa ich pochodzenia

${ }^{65}$ M. Pazdan: Prawo prywatne międzynarodowe. Warszawa 2012, s. 82. 
i ucieleśniają wolę zastosowania bez względu na prawo właściwe w normalnym toku rzeczy, zarazem nie popadając $\mathrm{w}$ konflikt $\mathrm{z}$ ordre public państwa siedziby sądu.

Powstaje jednak pytanie, czy w taki sam sposób oceniać ewentualność dopuszczenia do głosu przepisów wymuszających swoje zastosowanie modyfikujących ogólne reguły dziedziczenia ze względu na specyfikę danego składnika spadku, nienależących jednak do prawa państwa jego położenia. Wprawdzie zasięg uregulowań tego rodzaju ogranicza się zwykle do dóbr położonych na obszarze danego państwa, nie można jednak zupełnie wykluczyć sytuacji odmiennej. Może tu chodzić np. o postanowienia legis registrationis, dotyczące spadku po przedsiębiorcy, którego przedsiębiorstwo $\mathrm{w}$ znaczeniu przedmiotowym zlokalizowane jest na terytorium innego państwa.

O ile chodzi o tego rodzaju normy legis successionis, znajda one zastosowanie jako miarodajna dla przedmiotu rozstrzygnięcia część prawa właściwego. W takim wypadku może powstać co najwyżej konieczność ich skonfrontowania z odnoszacymi się do danego składnika spadku normami wymuszającymi pochodzącymi z państwa jego położenia. Co jednak w przypadku tego rodzaju regulacji państwa trzeciego bądź państwa siedziby sądu? Osobiście nie dostrzegam w treści art. 30 rozporządzenia przeszkód w ich dopuszczeniu do głosu. Podstawą mogłyby stać się także i tutaj normy kolizyjne państwa siedziby sądu odnoszące się do przepisów wymuszających swoje zastosowanie - w naszym przypadku art. 8 PrPrywM z 2011 r. Wydaje się jednak, iż kwestia ta powinna zostać poddana przez są krajowy ocenie TSUE w trybie art. 267 TFUE.

Przedstawione powyżej wątpliwości ujawniające się na tle aktualnego brzmienia art. 30 rozporządzenia skłaniaja jednak moim zdaniem do rozważenia jego nowelizacji. Mogłaby ona obejmować następujące zmiany: - wprowadzenie do rozporządzenia definicji przepisów wymuszających swoje zastosowanie wzorowanej na rozwiązaniu znanym z art. 9 ust. 1 rozporządzenia Rzym I oraz nadanie art. 30 tytułu „Przepisy wymuszające swoje zastosowanie”. Pozwoliłoby to rozstrzygnaćc spór co do charakteru norm, do których odnosi się omawiany przepis, zarazem podkreślając ich wyjątkowy charakter oraz znaczenie tkwiącego w nich pierwiastka realizacji interesu publicznego państwa pochodzenia, co powinno służyć ograniczeniu ryzyka nadużywania omawianego instrumentu;

- wyraźne dopuszczenie zastosowania w sprawach spadkowych przepisów wymuszających swoje zastosowanie innych niż objęte dotychczasowym brzmieniem art. 30, zarówno przynależnych do porządku prawnego forum, jak i innych państw ściśle związanych z dana sprawa, przy czym ocena istnienia takiego związku, a także celowo- 
ści dopuszczenia do głosu tego rodzaju przepisów w okolicznościach konkretnej sprawy pozostawałaby w gestii sądu. Rozwiązanie takie gwarantuje elastyczność na etapie rozstrzygnięcia i zwiększa szanse na uznanie i wykonalność orzeczenia w państwie pochodzenia danej normy imperatywnej.

Konsekwencja takiego rozwiązania byłaby także odpowiednia zmiana treści motywu 54 preambuły do rozporządzenia. Obok wyeliminowania wprowadzającego w błąd określenia „państwo członkowskie”, pozostawionego omyłkowo pomimo zmian w samym merytorycznym tekście rozporządzenia, powinien on wyraźnie dopuszczać odwołanie się do wyjątków opartych na przepisach wymuszających swoje zastosowanie, równocześnie - jak ma to miejsce w przypadku rozporządzeń Rzym I i Rzym II - podkreślając wyjątkowy charakter tego instrumentu. 